\title{
UPAYA PEMBERIAN PENGHARGAAN UNTUK MEWUJUDKAN KEDISIPLINAN GURU SD NEGERI WULUNGSARI DALAM MENGERJAKAN ADMINISTRASI KELAS
}

\author{
Yudiyanti $^{1}$, Pebria Dheni Purnasari ${ }^{2}$ \\ ${ }^{1}$ SDN Wulungsari, Wonosobo-Indonesia \\ Email: yudiyanti2017@gmail.com \\ ${ }^{2}$ Program Studi PGSD, Institut Shanti Bhuana, Bengkayang-Indonesia \\ Email: pebria.dheni@shantibhuana.ac.id
}

(Received: 28 Desember 2020; Reviewed: 04 February-2021; Accepted: 06 February-2021; Available online: Maret-2021; Published: Maret-2021)

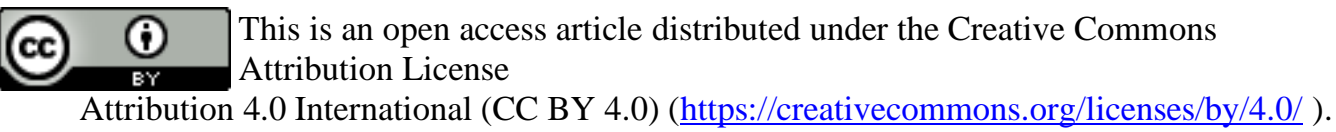

\author{
ARTIKEL INFO \\ Kata Kunci: \\ Penghargaan; \\ Kedisiplinan; \\ Administrasi Kelas;
}

\begin{abstract}
Abstrak. Tujuan penelitian ini adalah untuk mengetahui peningkatan kedisiplinan guru SDN Wulungsari melalui pemberian penghargaan dalam mengerjakan administrasi kelas. Subjek penelitian ini adalah guru kelas I s/d VI di SDN Wulungsari Kec. Selomerto Kab. Wonosobo. Pendekatan yang digunakan adalah deskriptif kualitatif dengan metode Penelitian Tindakan Sekolah (PTS). Teknik pengumpulan data menggunakan observasi dan dokumentasi. Selanjutnya data yang telah diperoleh dianalis dengan teknik analisis interaktif dari model Miles dan Huberman, yakni pengumpulan data, reduksi data, dan penarikan kesimpulan. Hasil penelitian menunjukkan bahwa data awal kegiatan penilaian pengerjaan administrasi guru kelas I s/d VI mencapai skor ratarata 29,33 dengan kategori gagal. Setelah dilaksanakan pembinaan dan program pemberian penghargaan untuk mengerjakan administrasi kelas tahap berikutnya diperoleh hasil skor rata-rata 74 dengan kategori baik. Kondisi tersebut menunjukkan bahwa ada peningkatan yang signifikan dalam hal kedisplinan, terbukti pada kondisi awal banyak guru yang lalai atau malas mengerjakan administrasi kelas sehingga hasilnya termasuk ke dalam kategori gagal. Setelah diberikan perlakuan yakni pembinaan dan program pemberian penghargaan pada guru yang dapat menyelesaikan administrasi kelas dengan baik, maka guru yang lainpun mulai disiplin dalam mengerjakan administrasi kelas. Jadi, dapat disimpulkan bahwa pemberian penghargaan mampu meningkatkan kedisiplinan guru dalam mengerjakan administrasi kelas.
\end{abstract}

\begin{abstract}
The purpose of this study was to find out that through giving awards it can improve the discipline of SDN Wulungsari teachers in working on classroom administration. The subjects were teachers of grades I to VI at SDN Wulungsari Kec. Selomerto Kab. Wonosobo. The approach is descriptive qualitative with the School Action Research (PTS) method. Data collection techniques using observation and documentation. Initial data on the classroom administration work assessment activities for class I to VI teachers without prior notification
\end{abstract}


turned out to be an average score of 29.33 with failed category. After implementation of coaching and award program to work on the next stage of class administration and reassessment, the results an average score of 74 in a good category. This condition shows there is a significant increase in discipline, as evidenced by the initial condition that many teachers are negligent or lazy to do classroom administration so that the results fall into the category of failure. After giving treatment, namely coaching and awarding programs for teachers who can complete class administration well, other teachers begin to be disciplined in working on classroom administration. The conclusion is giving awards can increase teacher discipline in doing classroom administration.

\section{PENDAHULUAN}

Undang-undang nomor 20 tahun 2003 menjelaskan bahwa pendidikan adalah usaha secara sadar dan terencana untuk mencapai tujuan tertentu yaitu meningkatkan kualitas sumber daya manusia. Upaya untuk meningkatkan kualitas sumber daya manusia dapat dilakukan melalui proses pembelajaran di sekolah. Dalam usaha meningkatkan kualitas sumber daya manusia pada satuan pendidikan, guru merupakan komponen sumber daya manusia yang harus dibina dan dikembangkan terus-menerus. Seorang guru yang profesional dan berkualitas akan membentuk peserta didik yang berkualitas pula. Guru merupakan penentu keberhasilan melalui kinerjanya pada tataran institusional dan eksperiensial, sehingga upaya meningkatkan mutu pendidikan dapat dimulai dari aspek guru dan tenaga kependidikan lainnya yang menyangkut kualitas mutu pendidikan. Oleh karena itu, untuk membentuk seorang guru yang professional diperlukan adanya pelatihan, pembinaan, dan penilaian yang disertai pemberian reward atau penghargaan yang setinggi-tingginya secara rutin dan konsisten untuk pelaksanaan pengerjaan administrasi kelas.

Mutu pendidikan dapat ditingkatkan melalui pembinaan guru. Pembinaan guru dapat dilakukan oleh kepala sekolah, hal ini bertujuan untuk memantau dan meningkatkan kompetensi guru, sehingga dapat diketahui apakah guru tersebut sudah dapat dikategorikan profesional atau belum. Salah satu upaya yang dapat dilakukan dalam rangka pembinaan untuk memantau dan meningkatkan kompetensi guru adalah dengan melakukan supervisi. Peraturan Menteri Pendidikan Nasional nomor 13 tahun 2007 menyatakan bahwa 5 dimensi kompetensi yaitu kompetensi kepribadian, kompetensi manajerial, kompetensi supervisi, kompetensi kewirausahaan dan kompetensi sosial harus dikuasai oleh kepala sekolah. Berdasar ketentuan tersebut tepatlah jika kepala sekolah melaksanakan tugas pokok dan fungsinya sebagai supervisor dengan cara melakukan kegiatan pembinaan dan penilaian terhadap guru dalam mengerjakan administrasi kelas yang merupakan tanggungjawab kesehariannya yaitu merencanakan program pembelajaran, pelaksanaan program, dan evaluasi proram pembelajaran. Kepala Sekolah selaku penulis melakukan supervisi manajerial karena berhubungan dengan pengerjaan administrasi kelas. Secara umum tujuan supervisi yang difokuskan kepada guru adalah untuk meningkatkan mutu kinerja dari guru itu sendiri, seperti memahami tujuan pendidikan, memahami keadaan dan kebutuhan siswa, meningkatkan kualitas mengajar baik untuk prestasi siswa maupun penerapan strategi dan pemanfaatan alat peraga. Tujuan akhir pendidikan di SD adalah agar siswa memiliki pengetahuan, keterampilan, dan sikap yang diperoleh melalui penerapan kurikulum yang berlaku. Usaha pelaksanaan kurikulum ke arah pencapaian tujuan pendidikan adalah melalui sistem 
pengerjaan administrasi yang baik. Namun kondisi yang demikian belum tercermin pada kondisi yang sesungguhnya, artinya guru belum menunjukkan kinerja yang profesional, karena kurangnya pembinaan yang dilakukan kepada guru dan ketidaksiapan guru ketika penilaian dilaksanakan. Berdasarkan hasil observasi, kondisi di SDN Wulungsari menunjukkan tidak hanya guru baru namun beberapa guru yang lama bahkan sudah mengajar selama bertahun-tahun pun masih mengalami ketidaksiapan ketika akan dinilai. Hal tersebut terbukti dengan sikap bingung dan tidak siap ketika akan dinilai, dan setelah dinilai menunjukkan hasil dengan kategori gagal yakni total nilai dari 6 guru kelas memperoleh angka 176:6 = 29,33. Kondisi awal pengerjaan administrasi tidak konsisten, ditemukan juga bahwa hanya baru beberapa guru yang mengerjakan administrasi kelas meskipun belum maksimal hasilnya, serta belum semua administrasi kelas dikerjakan dengan baik dan benar.

Mulyasa (2011) sebelumnya telah memaparkan bahwa kegiatan supervisi dapat dilakukan oleh kepala sekolah yang berperan sebagai supervisor. Kesadaran dan keterampilan melaksanakan tugas dengan tanggung jawab merupakan salah satu indikator dari ketercapaian peningkatan kinerja guru. Hal tersebut dapat menjadi bukti dari keberhasilan kepala sekolah sebagai supervisor. Kepala sekolah harus kreatif dalam memotivasi guru untuk mengerjakan administrasi kelas secara rutin, benar, dan lengkap.

Pemberian penghargaan atau reward merupakan salah satu alternatif kreatifitas kepala sekolah selaku penulis dalam memotivasi guru untuk disiplin mengerjakan administrasi kelas, karena pemberian penghargaan atau reward sangat mudah dilaksanakan di samping murah dan tidak berisiko. Penghargaan dapat dikatakan sebagai salah satu bentuk kepemimpinan kepala sekolah dalam meningkatkan mutu kinerja para guru. (Kautsar, Yusrizal, \& Bahrun, 2020) menyatakan bahwa diperlukan kepemimpinan kepala sekolah yang baik untuk bisa menciptakan lingkungan yang kondusif. Tidak bisa dipungkiri bahwa setiap manusia butuh disanjung, dipuji, diakui keberadaanya dan dihargai karyanya. Oleh karena itu tepat sekali jika pemberian penghargaan atau reward diterapkan sebagai salah satu cara memotivasi dan menghargai guru dalam melaksanakan tugas profesinya. Hal ini sebagaimana diungkapkan oleh (Manik, 2019) bahwa penghargaan atau reward merupakan upaya manajemen sumber daya manusia yang dilakukan oleh kepala sekolah untuk meningkatkan kinerja. Lebih lanjut (Rahmanto, 2018) menyatakan bahwa pemberian penghargaan mampu meningkatkan kedisiplinan guru. Melalui penjabaran dan penjelasan di atas, maka kepala sekolah SDN Wulungsari melakukan usaha mewujudkan disipilin tinggi bagi guru SDN Wulungsari dalam mengerjakan administrasi kelas melalui pemberian penghargaan atau reward.

Berdasarkan latar belakang yang telah dipaparkan, terlihat bahwa guru kelas SDN Wulungsari belum disiplin dalam mengerjakan administrasi kelas, dikarenakan belum paham tentang administrasi kelas secara mendalam, kurangnya penghargaan dari kepala sekolah, guru belum memberikan pelaporan administrasi yang lengkap sehingga saat kepala sekolah melakukan penilaian administrasi kelas, guru-guru bingung dan tidak siap akibatnya hasil penilaian kategori gagal. Dalam mengatasi hal tersebut, penulis mencoba melakukan peningkatan kedisiplinan administrasi kelas guru-guru SDN Wulungsari dengan mengadakan pembinaan dan memberikan penghargaan atau reward kepada guru yang mendapat nilai tinggi sehingga dengan upaya tersebut maka diharapkan guru-guru SDN Wulungsari akan tertib dan disiplin dalam mengerjakan administrasi kelas. Berikut adalah gagasan dari penulis dengan mengacu dari latar belakang permasalahan beserta teori yang dipaparkan, dan bila disajikan akan tampak seperti pada bagan 1 . 


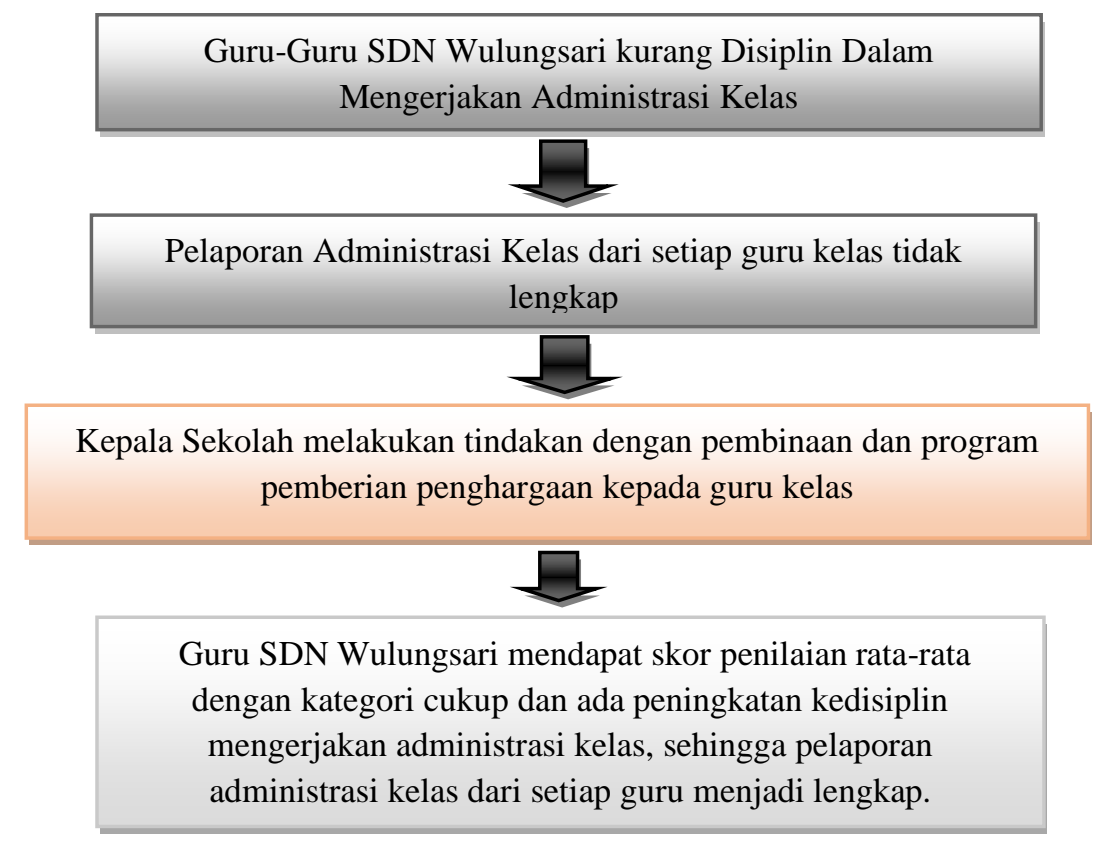

Gambar 1. Kerangka Berpikir

Berdasarkan latar belakang dan identifikasi masalah tersebut yang sudah dijelaskan dan dipaparkan tersebut, maka dapat ditentukan rumusan masalahnya yakni "apakah melalui pemberian penghargaan atau reward mampu mewujudkan disiplin tinggi bagi guru SDN Wulungsari dalam mengerjakan administrasi kelas?". Sejalan dengan rumusan masalah yang telah disusun, maka tujuan dari penelitian ini adalah untuk mengetahui bahwa melalui pemberian penghargaan atau reward dapat meningkatkan kedisiplinan guru SDN Wulungsari dalam mengerjakan administrasi kelas.

\section{METODE}

Pendekatan yang digunakan dalam penelitian ini adalah deskriptif kualitatif dengan metode Penelitian Tindakan Sekolah (PTS). Deskriptif kualitatif tersebut bermaksud agar dapat menjelaskan secara rinci cara pembinaan yang dilakukan kepala sekolah terhadap guru melalui penilaian pengerjaan administrasi kelas.

Penelitian ini dilakukan pada guru kelas satu sampai dengan guru kelas enam di SDN Wulungsari Kec. Selomerto Kab. Wonosobo, dengan tujuan untuk mendeskripsikan cara kepala sekolah dalam membina guru di SDN Wulungsari melaui pemberian penghargaan dalam penilaian pengerjaan administrasi kelas. Penelitian ini bersifat deskriptif kualitatif agar dapat menjelaskan secara rinci cara pembinaan yang dilakukan kepala sekolah terhadap guru melalui penilaian pengerjaan administrasi kelas.

Data yang dibutuhkan dalam penelitian ini dikumpulkan melalui teknik observasi dan dokumen administrasi kelas, selanjutnya dianalisis dengan teknik analisis interaktif dari Miles dan Huberman yakni dengan tahap pengumpulan data, reduksi data, dan verifikasi/ penarikan kesimpulan (Sugiyono, 2012).

Analisa data dimulai dengan melakukan pencarian data secara sistematis terhadap lembar observasi, 
catatan lapangan, dokumen, dan material lainnya untuk kemudian diinterpretasikan dan diberikan makna guna meningkatkan pemahaman peneliti terhadap fokus penelitian yang kemudian disajikan sebagai hasil penelitian. Dalam penelitian ini, data yang telah terkumpul dianalisis secara kualitatif deskriptif.

Data mengenai hasil penilaian administrasi kelas dianalisis dengan cara menghitung rata-rata nilai. Data yang diperoleh dari penilaian administrasi kelas masing-masing guru dapat ditentukan ketuntasan individu menggunakan analisis deskriptif prosentase dengan perhitungan:

$$
\begin{aligned}
& \text { Nilai }=\frac{\sum \times}{\mathrm{N}} \times 100 \\
& \text { Keterangan: } \\
& \begin{array}{c}
\sum \mathrm{x}=\text { Jumlah keseluruhan skor yang } \\
\text { diperoleh } \\
\mathrm{N}=\text { Jumlah keseluruhan skor } \\
\text { maksimal }
\end{array}
\end{aligned}
$$

Adapun kategori penggolongan rentang nilai akhir sebagai berikut:

$$
\begin{aligned}
& 80 \text { ke atas : baik sekali } \\
& 66-79 \text { : baik } \\
& 56-65 \text { : cukup } \\
& 46-55 \text { : kurang } \\
& 45 \text { ke bawah: gagal } \\
& \text { (Sudijono, 2008) }
\end{aligned}
$$

Adapun indikator keberhasilan dalam penelitian ini adalah jika sudah menggambarkan perubahan dari data awal dan data akhir dari kategori gagal menjadi kategori cukup

Penulis berusaha semaksimal mungkin untuk menciptakan hubungan sosial yang baik dengan semua guru dalam penelitian ini dengan cara pendekatan untuk penilaian administrasi kelas di SDN Wulungsari sehingga diharapkan penulis mampu memahami semua kinerja dan keadaan yang terjadi.

Adapun rencana tindakan yang dilakukan yaitu: (1) perencanaan, (2) pelaksanaan, (3) pengamatan, dan (4) refleksi.

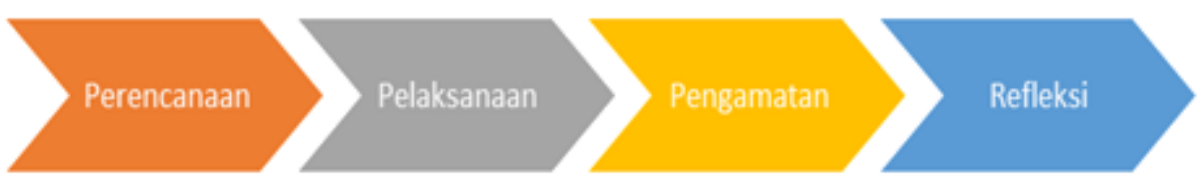

Gambar 2. Rencana Tindakan PTS

\section{1) Perencanaan}

Pada tahap ini penulis menentukan waktu, sasaran, dan instrumen yang digunakan. Adapun instrumen yang disiapkan adalah format instrumen penilaian, buku proses supervisi, buku rekap penilaian, buku tindak lanjut supervisi, dan buku laporan supervisi serta dokumentasi.

\section{2) Pelaksanaan}

Pada tahap ini penulis melakukan kunjungan kelas. Penulis masuk ke kelas dan meneliti buku administrasi guru dari guru kelas 1 sampai dengan guru kelas 6 dan memberikan penilaian pada lembar instrument penilaian administrasi kelas. Setelah perekapan penilaian maka dilakukan pembinaan tentang temuan dari hasil penilaian dan program pemberian penghargaan dengan tujuan agar ada perbaikan dari pengerjaan yang salah, peningkatan bagi pengerjaan yang yang sudah benar dan penyempurnaan bagi pengerjaan yang hampir maksimal.

\section{3) Pengamatan}

Pada tahap ini penulis melakukan pengamatan melalui pengecekan hasil penilaian pengerjaan administrasi kelas 1 sampai dengan kelas 6 , dan memeriksa kekurangan atau kesulitan guru dalam mengerjakan administrasi kelas serta menulis temuan-temuan. 


\section{4) Refleksi}

Pada tahap refleksi penulis mengadakan rapat untuk menyampaikan hasil rekap penilaian administrasi kelas kepada guru kelas 1 sampai dengan guru kelas 6 dan memberi penghargaan berupa uang Rp300.000,00 untuk peringkat 1, Rp200.000,00 untuk peringkat 2, dan Rp100.000,00 bagi peringkat 3 serta penyerahan bukti penilaian berupa instrumen penilaian kemudian dilanjutkan makan bersama. Penulis beserta guru kelas melakukan refleksi dengan membahas kekurangan dan kelebihan masing-masing serta merencanakan tindak lanjut.

\section{HASIL DAN PEMBAHASAN}

\section{Hasil Penelitian}

Kondisi awal Kepala Sekolah sebagai peneliti melakukan observasi kepada semua guru kelas SDN Wulungsari yang berjumlah 6 guru. Observasi dilakukan dengan cara Kepala Sekolah melakukan penilaian administrasi kelas kepada semua guru kelas SDN wulungsari dengan menggunakan instrumen penilaian administrasi kelas tanpa diberitahu terlebih dahulu.

Tabel 1. Data Kondisi Awal

\begin{tabular}{ccc}
\hline Nama & Skor & Kategori \\
\hline Guru 1 & 35 & Gagal \\
\hline Guru 2 & 31 & Gagal \\
\hline Guru 3 & 34 & Gagal \\
\hline Guru 4 & 32 & Gagal \\
\hline Guru 5 & 32 & Gagal \\
\hline Guru 6 & 44 & Gagal \\
\hline Total & $\mathbf{1 7 6 : 6 = 2 9 , 3 3}$ & Gagal \\
\hline
\end{tabular}

Dari tabel di atas tercatat bahwa guru kelas 1 hingga guru kelas 6 mendapat skor di bawah 45 dengan kategori gagal. Dari hasil tersebut, maka perlu diadakan pembinaan dan program pemberian penghargaan supaya ada peningkatan skor dalam mengerjakan administrasi kelas.
Setelah dilakukan pembinaan dan program pemberian penghargaan, maka penulis mengadakan kegiatan penilaian tahap berikutnya yang diperoleh hasil seperti tabel di bawah ini.

Tabel 2. Data Kondisi Akhir

\begin{tabular}{ccc}
\hline Nama & Skor & Kategori \\
\hline Guru 1 & 82 & Baik Sekali \\
\hline Guru 2 & 62 & Cukup \\
\hline Guru 3 & 70 & Baik \\
\hline Guru 4 & 73 & Baik \\
\hline Guru 5 & 80 & Baik Sekali \\
\hline Guru 6 & 77 & Baik \\
\hline Total & $\mathbf{4 4 4 : 6 = 7 4}$ & Baik \\
\hline
\end{tabular}

Memperhatikan tabel di atas, jika dijumlah total maka nilai rata - rata guru SDN Wulungsari adalah 444:6 = 74 sudah berada pada kategori baik. Nilai skor terendah diraih oleh guru kelas 2 dengan skor 62, sedangkan nilai skor tertinggi diraih oleh guru 1 dengan skor 82. Jika diperingkat maka peringkat 1 adalah guru kelas 1 dengan skor 82 , peringkat 2 adalah guru kelas 5 dengan skor 80, dan peringkat 3 adalah guru kelas 6 dengan skor 77 . Hal ini sudah menunjukkan peningkatan yang 
2021 | Yudiyanti., Purnasari, P.D., Upuaya Pemeberian Penghargaan untuk Mewujudkan Kedisiplinan Guru SD Negeri Wulungsari dalam Mengerjakan Administrasi Kelas

signifikan karena sudah mampu melewati kategori gagal dan mampu melewati 2

tahapan kategori kurang dan kategori cukup.

Tabel 3. Perbandingan data awal dan data akhir

\begin{tabular}{ccc}
\hline Pelaksanaan Kegiatan & Data Awal & Data Akhir \\
\hline Total Skor & $176: 6=29,33$ & $446: 6=74$ \\
\hline Kategori & Gagal & Baik \\
\hline
\end{tabular}

Dari data awal kegiatan penilaian pengerjaan administrasi kelas guru kelas 1 sampai dengan guru kelas 6 tanpa pemberitahuan terlebih dahulu, ternyata diperoleh hasil skor rata-rata sebesar 176:6 $=29,33$ dengan kategori gagal. Kemudian dilaksanakan pembinaan dan program pemberian penghargaan untuk mengerjakan administrasi kelas tahap berikutnya. Setelah dilaksanakan proses penilaian pengerjaan administrasi berikutnya diperoleh hasil 446:6 = 74 dengan kategori baik. Melalui pemberian penghargaan terjadi peningkatan hasil 44,67 skor.

\section{Pembahasan}

Pelaksanaan pemberian penghargaan di SDN Wulungsari berhasil dilaksanakan dan dapat meningkatkan kedisiplinan guru SDN Wulungsari dalam mengerjakan administrasi kelas. Hal tersebut terbukti dari hasil penelitian yang didapat, yakni pada kondisi awal sebelum dilakukan pemberian penghargaan, tercatat bahwa guru kelas 1 hingga guru kelas 6 SDN Wulungsari mendapat skor di bawah 45 dengan kategori gagal dalam penilaian administrasi kelas yang diadakan oleh kepala sekolah. Kemudian dari hal tersebut, kepala sekolah SDN Wulungsari memberikan pembinaan mengenai pentingnya administrasi kelas dan melaksanankan program penghargaan supaya ada peningkatan skor dalam mengerjakan administrasi kelas. Setelah dilakukan pembinaan dan program pemberian penghargaan, maka penulis mengadakan kegiatan penilaian tahap berikutnya yang diperoleh hasil nilai ratarata guru SDN Wulungsari adalah 74 dan berada pada kategori baik. Hasil tersebut ternyata signifikan dapat membantu meningkatkan kedisiplinan guru SDN Wulungsari dalam administrasi kelas, disebut signifikan karena dapat meningkatkan hasil dari kategori gagal menjadi kategori baik. Hasil kategori baik tersebutpun telah dapat menjawab indikator keberhasilan yang disusun, yakni jika hasil penelitian sudah menggambarkan perubahan dari data awal dan data akhir dari kategori gagal menjadi kategori cukup. Melalui hal tersebut maka penelitian dikatakan berhasil dan selesai dengan hasil bahwa pemberian penghargaan dapat meningkatkan kedisiplinan guru-guru di SDN Wulungsari dalam mengerjakan administrasi kelas. Hal ini menunjukkan bahwa penghargaan dapat mendorong tumbuhnya hal yang positif sehingga mencapai sasaran yang ditetapkan. Hasil ini selaras dengan temuan penelitian yang dilakukan oleh (Mardiana, 2019) yakni pemberian penghargaan memberikan dampak yang positif diantaranya membuat para guru menjadi lebih giat dan berusaha dalam meningkatkan dan memperbaiki kinerjanya. Hal serupa juga dikemukakan oleh (Rahmanto, 2018) bahwa berdasarkan hasil penelitiannya penghargaan atau reward dapat meningkatkan kedisiplinan guru. Jika dicermati upaya pemberian penghargaan merupakan upaya yang dilakukan kepala sekolah demi mencapai satu tujuan tertentu. Dalam hal ini pemberian penghargaan dapat dikatakan sebagai salah satu bentuk kepemimpinan kepala sekolah guna menciptakan lingkungan kerja yang kondusif serta mencapai tujuan tertentu dalam hal ini adalah kedisiplinan. (Kautsar, Yusrizal, \& Bahrun, 2020) menyatakan bahwa untuk mewujudkan kedisipinan maka diperlukan 
kemampuan kepala sekolah dalam memimpin dan mengelola setiap komponen sekolah. Sehingga tercipta lingkungan yang kondusif, oleh karena itu pemberian penghargaan sebagaimana juga dilakukan oleh (Manik, 2019) dapat menjadi salah satu wujud kepemimpinan kepala sekolah dalam meningkatkan mutu atau kualitas kerja para guru.

\section{KESIMPULAN}

Pemberian penghargaan terbukti mampu meningkatkan kedisplinan guru dalam mengerjakan administrasi kelas. Melalui pemberian penghargaan, guru terdorong untuk mengerjakan administrasi kelas karena adminitrasi kelas merupakan kewajiban yang memang harus diselesaikan guru sebagai bukti fisik laporan kerjanya. Adanya penghargaan membuat guru yang semula kurang disiplin dalam mengerjakan administrasi kelas menjadi lebih disiplin, hal ini dibuktikan melalui berkas administrasi kelas yang terkumpul saat dilakukan penilaian. Kondisi ini menunjukkan bahwa ada peningkatan yang signifikan dalam hal kedisplinan, terbukti pada kondisi awal banyak guru yang lalai atau malas mengerjakan administrasi kelas sehingga hasilnya termasuk kategori gagal. Setelah diberikan perlakuan yakni pembinaan dan program pemberian penghargaan pada guru yang dapat menyelesaikan administrasi kelas dengan baik, maka guru yang lain pun mulai disiplin dalam mengerjakan administrasi kelas. Dengan demikian dapat disimpulkan bahwa pemberian penghargaan mampu meningkatkan kedisiplinan guru dalam mengerjakan administrasi kelas.

Berdasarkan simpulan di atas, maka penulis menyarankan:

1) Kepala Sekolah hendaknya melaksanakan tugas sebagai supervisor secara rutin minimal dua kali dalam satu semester tiap tahunnya. Kepala Sekolah hendaknya menerapkan pemberian penghargaan dalam melaksanakan kegiatan penilaian sebagai perangsang meningkatkan kedisiplinan bagi guru dalam mengerjakan administrasi kelas.

2) Guru Kelas harus dapat untuk lebih disiplin lagi dalam pengelolaan dan pelaporan administrasi kelasnya.

\section{UCAPAN TERIMA KASIH}

Ucapan terima kasih diberikan kepada Dinas Pendidikan Kabupaten Wonosobo atas dukungannya. Terima kasih juga diberikan kepada para guru SD Negeri Wulungsari Wonosobo atas kerjasama baiknya dan semangatnya dalam melakukan disiplin administrasi kelas.

\section{DAFTAR PUSTAKA}

Depdiknas. (2007). Kamus Besar Bahasa Indonesia Edisi Ketiga. Jakarta: Balai Pustaka.

Dharma, S. (2013). Manajemen Kinerja Falsafah Teori dan Penerapannya. Yogyakarta: Pustaka Pelajar.

Hasibuan, M. (2012). Manajemen Sumber Daya Manusia Perusahaan. Bandung: PT. Bumi Aksa.

Kautsar, M., Yusrizal, \& Bahrun. (2020). Strategi Kepemimpinan Kepala Sekolah dalam Meningkatkan Kedisiplinan Guru Pada MAN 1 Kabupaten Aceh Utara. Jurnal Visipena, 11(2), 364-376.

Manik, R. (2019). Pemberian Reward dan Punishment Untuk Meningkatkan Etos Kerja Guru. Jurnal Jumpa, 7, 80-95.

Mardiana. (2019). Upaya Meningkatkan Disiplin Guru Melalui Sistem Reward dan Punishment. Jurnal Global Edukasi, 2(4), 313-320.

Mulyasa. (2011). Manajemen Berbasis Sekolah, Konsep, strategi dan Implementasi. Bandung: PT Remaja Rosdakarya. 
Purwanto, N. (2006). Psikologi Pendidikan. Bandung: PT Remaja Rosdakarya.

Rahmanto, A. (2018). Peningkatan Kedisiplinan Guru Melalui Pemberian Reward di SD Muhhamadiyah Sapen Yogyakarta. Tajdidukasi, 8(2), 125-136.

Siagian, P. (2011). Organisasi Kepemimpinan Dan Perilaku Administrasi. Jakarta: Gunung Agung.

Sudijono, A. (2008). Pengantar Evaluasi Pendidikan. Jakarta: Raja Grafindo Persada.

Sugiyono. (2012). Metode Penelitian Kuantitatif Kualitatif dan $R \& B$. Bandung: Alfabeta.

Tu'u, T. (2004). Peran Disiplin pada Perilaku dan Prestasi Siswa. Jakarta: Grasindo.

Wantah, M. J. (2005). Pengembangan Disiplin Dan Pembentukan Moral Pada Anak Usia Dini. Jakarta: Departemen Pendidikan Nasional. 